\title{
FGF22 wt Allele
}

National Cancer Institute

\section{Source}

National Cancer Institute. FGF22 wt Allele. NCI Thesaurus. Code C120955.

Human FGF22 wild-type allele is located in the vicinity of 19p13.3 and is approximately 4 $\mathrm{kb}$ in length. This allele, which encodes fibroblast growth factor 22 protein, plays a role in both glucose homeostasis and lipid metabolism. 